\title{
Serum endostatin levels are elevated in colorectal cancer and correlate with invasion and systemic inflammatory markers
}

\author{
T Kantola ${ }^{1,2,3}$, J P Väyrynen ${ }^{1,2,3}$, K Klintrup ${ }^{2,3,4}$, J Mäkelä2,3,4 S M Karppinen ${ }^{5}$, T Pihlajaniemi ${ }^{5}$, \\ H Autio-Harmainen ${ }^{1,2,3}$, T J Karttunen ${ }^{1,2,3}$, M J Mäkinen ${ }^{1,2,3}$ and A Tuomisto*,1,2,3 \\ ${ }^{1}$ Department of Pathology, University of Oulu, POB 5000, 90014 Oulu, Finland; ${ }^{2}$ Oulu University Hospital, POB 21, 90029 Oulu, \\ Finland; ${ }^{3}$ Medical Research Center Oulu, POB 21, 90029 Oulu, Finland; ${ }^{4}$ Department of Surgery, University of Oulu, POB 5000, \\ 90014 Oulu, Finland and ${ }^{5}$ Faculty of Biochemistry and Molecular Medicine and Biocenter Oulu, University of Oulu, POB 5400, \\ 90014 Oulu, Finland
}

Background: Endostatin, a fragment of collagen XVIII, is an endogenous angiogenesis inhibitor with anti-tumour functions. However, elevated circulating endostatin concentrations have been found in several human cancers including colorectal cancer (CRC).

Methods: Serum endostatin levels were measured by enzyme-linked immunoassay from a series of 143 patients with CRC and from 84 controls, and correlated with detailed clinicopathological features of CRC, serum leukocyte differential count and C-reactive protein (CRP) levels.

Results: Patients with CRC had higher serum endostatin levels than the controls $(P=0.005)$, and high levels associated with age, tumour invasion through the muscularis propria and poor differentiation, but not with metastases. Endostatin levels showed a positive correlation with the markers of systemic inflammatory response and a negative correlation with the densities of tumourinfiltrating mast cells and dendritic cells. Collagen XVIII was expressed in tumour stroma most strikingly in blood vessels and capillaries, and in the muscle layer of the bowel wall.

Conclusions: Elevated endostatin levels in CRC correlate with systemic inflammation and invasion through the muscularis propria. Increased endostatin level may be a result of invasion-related cleavage of collagen XVIII expressed in the bowel wall. The negative correlations between serum endostatin and intratumoural mast cells and immature dendritic cells may reflect angiogenesis inhibition by endostatin.

Colorectal cancer (CRC) is one of the most common malignancies and among the leading causes of death in the industrialised world (Siegel et al, 2013). As in all solid tumours, angiogenesis is crucial for CRC growth, progression and metastasis, and tumours cannot grow beyond the size of few millimetres without angiogenesis (Folkman et al, 1963). In CRC, the control of normal physiologic angiogenesis inhibition is disrupted, allowing neovascularisation that supports tumour growth (Folkman and Klagsbrun, 1987; Jain, 2005).
Endostatin, one of the most potent inhibitors of angiogenesis, is a proteolytically cleaved $20-\mathrm{kDa}$ C-terminal fragment of a vascular and epithelial basement membrane protein, collagen XVIII (O’Reilly et al, 1997). Endostatin inhibits angiogenesis via its ability to restrict endothelial cell proliferation (O'Reilly et al, 1997) and migration (Yamaguchi et al, 1999) and to induce endothelial cell apoptosis (Dhanabal et al, 1999). The antitumour effect of endostatin is not merely restricted to angiogenesis and endothelial cells, but it also directly inhibits tumour cell migration and

*Correspondence: Dr A Tuomisto; E-mail: anne.tuomisto@oulu.fi

Received 24 March 2014; revised 1 July 2014; accepted 21 July 2014; published online 19 August 2014

(c) 2014 Cancer Research UK. All rights reserved 0007-0920/14 
invasion (Wilson et al, 2003; Folkman, 2006). Endostatin binds to several cell membrane proteins including $\alpha 5 \beta 1$ and $\alpha \mathrm{v} \beta 3$ integrins (Rehn et al, 2001; Faye et al, 2009), glypicans (Karumanchi et al, 2001), and VEGF receptors 1, 2 and 3 (Kim et al, 2002; Kojima et al, 2008). It inhibits the activation of proMMP-2, pro-MMP-9 and proMMP-13 and the catalytic activity of MMP-2 and membrane type -1 MMP (Kim et al, 2000; Nyberg et al, 2003). The broad range of the molecular targets of endostatin suggests that it can affect the behaviour of the cells via numerous pathways. The extensive influence of endostatin on endothelial cells is based on its effect on gene expression: By using genome-wide microarray analysis, Abdollahi et al, 2004 showed that endostatin treatment of cultured human endothelial cells resulted in significant changes in $12 \%$ of the genes analysed.

Elevated circulating endostatin concentrations have been found in several human cancers. Despite the acknowledged antiangiogenic functions of endostatin, higher serum endostatin levels are associated with poor differentiation and advanced stage in CRC, gastric cancer and bladder cancer (Li et al, 2012; Szarvas et al, 2012) and with poor prognosis of the patient in bladder cancer, non-small cell lung cancer, gastric cancer and soft tissue sarcoma (Feldman et al, 2001; Suzuki et al, 2002; Woo et al, 2006; Szarvas et al, 2012). The effect of endostatin on endothelial cells depends on the length of exposure (Li et al, 2005), the type of endothelial cells (Schmidt et al, 2004) and the type of growth factor inducing endothelial cell proliferation (Delaney et al, 2006). Finally, the composition of the extracellular matrix with which the cells are in contact modifies the effect of endostatin (Delaney et al, 2006). Interestingly, endostatin has a tumour-specific optimal inhibition concentration, higher and lower dosages having less inhibitory effect (Celik et al, 2005; Tjin Tham Sjin et al, 2006). All in all, endostatin is associated with several fundamental aspects of cancer including tumour cell differentiation, cancer angiogenesis and lymphangiogenesis, and inflammatory cell infiltration (Brideau et al, 2007; Seppinen and Pihlajaniemi, 2011).

In this study, we aimed to enlighten the significance of serum endostatin levels in CRC patients. We measured systemic endostatin levels in $143 \mathrm{CRC}$ patients and 84 healthy controls matched for age and gender and correlated the endostatin levels with clinicopathological parameters. Furthermore, in order to evaluate the contribution of both local and systemic inflammation to serum endostatin levels in CRC, we analysed the association of serum endostatin levels with local inflammatory cell densities in CRC tissue and with systemic inflammation as determined by C-reactive protein (CRP), blood leukocyte counts, neutrophil/ lymphocyte ratio (NLR) and modified Glasgow prognostic score (mGPS) (Roxburgh and McMillan, 2010).

\section{MATERIALS AND METHODS}

Patients and sampling. All newly diagnosed CRC patients operated on in Oulu University Hospital between April 2006 and January 2010 ( $n=344)$ were introduced for this prospective study. Blood samples and surgical specimens were originally collected from 148 patients, who had signed an informed consent to participate and were eligible for the study. Thirty-two of the 148 patients $(21.6 \%)$ received preoperative radiotherapy or chemoradiotherapy (RT/CRT) and were excluded from the inflammatory cell analyses because RT/CRT is a potential confounding factor affecting the local tumour characteristics and reducing inflammatory reaction of the tumours (Nagtegaal et al, 2002a). The RT/CRT control group was a stage-matched control group randomly selected from rectal cancer patients who had not received preoperative RT/CRT. Age- and sex-matched control serum samples were acquired from healthy voluntary blood donors
(Finnish Red Cross, Oulu, Finland; $n=36$, age $<65$ years) and cataract surgery patients (Oulu University Hospital; $n=50$, age $\geqslant 65$ years). The samples were centrifuged, and serum was stored at $-70{ }^{\circ} \mathrm{C}$ until further analysis. The study set-up is previously described (Kantola et al, 2012). From the blood samples, leukocyte differential count was utilised in the calculation of NLR, and CRP and serum albumin were utilised for the assessment of mGPS $\left(0=\mathrm{CRP} \leqslant 10 \mathrm{mgl}^{-1}, \quad 1=\mathrm{CRP}>10 \mathrm{mgl}^{-1}\right.$, and $2=\mathrm{CRP}$ $>10 \mathrm{mgl}^{-1}$ and albumin $<35 \mathrm{gl}^{-1}$ ). (Roxburgh and McMillan, 2010). The blood NLR and mGPS are systemic inflammatory markers found to have significant prognostic value in CRC (Roxburgh and McMillan, 2010).

Collagen XVIII and inflammatory cell immunohistochemistry. Immunohistochemical analyses of collagen XVIII (rabbit polyclonal antibody QH48) and inflammatory cell markers were carried out on formalin-fixed paraffin-embedded 3.5- $\mu \mathrm{m}$ sections as described earlier (Saarela et al, 1998; Väyrynen et al, 2013). The inflammatory cell markers used in this study were CD3 (T cells), CD8 (cytotoxic $\mathrm{T}$ cells), FoxP3 (regulatory $\mathrm{T}$ cells), CD68 (monocyte-macrophage lineage cells), neutrophil elastase (neutrophilic granulocytes), mast cell tryptase (mast cells), CD83 (mature dendritic cells (DCs)) and CD1a (immature DCs) (Väyrynen et al, 2013). Bound antibodies were detected using peroxidase-based EnVision kit (Dako, Copenhagen, Denmark). 3,3'-Diaminobenzidine was used as the chromogen and all sections were counterstained with haematoxylin. Cells were quantitated by using image analysis and the quantity of blood vessels surrounded by collagen XVIII-expressing basement membrane was evaluated on a 4-tiered scale from the captured images of the invasive front and the tumour stroma (Väyrynen et al, 2012, 2013).

Serum endostatin assays. Endostatin concentrations were measured from serum samples of 148 CRC patients and 84 age- and sex-matched controls. Serum endostatin levels were determined by using the commercial Quantikine Human Endostatin Immunoassay (R\&D Systems, Minneapolis, MN, USA) according to the manufacturer's instructions. Previously produced recombinant human endostatin (Rehn et al, 2001) was used as a control in the assay. Colour intensity of the samples was measured with a Victor3 plate reader (PerkinElmer, Waltham, MA, USA). All the assays were performed in duplicate and the mean values were used as the final concentration. Finally, endostatin measures of 143 CRC patients, 113 CRC patients without RT/CRT and 84 controls were included for the analyses. One of the samples was ignored because of having an endostatin value above the standard curve and four samples were left aside because the measured duplicates differed from each other by at least $20 \%$.

Follow-up. All CRC patients who underwent surgery were followed up for tumour recurrence at regular intervals for up to 5 years. For disease-free survival (DFS) analyses, the time to the end point was calculated from the date of diagnosis of CRC until the date of locoregional or systemic CRC recurrence. The DFS analysis included $81.4 \%$ (92 out of 113 ) of the patients, while excluded patients $(18.6 \%, 21$ out of 113$)$ underwent palliative operation. The median follow-up time was 51.5 months (range 0.1-60 months). For cancer-specific survival (CSS) and overall survival (OS) analyses, all 113 patients were included, with a median follow-up of 57.9 months (range 0.1-60 months). The OS for all patients was $65.5 \%$ (74 out of 113).

Statistical analysis. Normally distributed continuous variables are presented as mean (standard deviation, s.d.), whereas other continuous variables are presented as median (interquartile range). IBM SPSS Statistics 19 was used for statistical analysis (IBM, Chicago, IL, USA). Statistical significances of the differences in serum endostatin levels between the different study groups and age, gender, stage, grade and tumour location categories were 
analysed by Mann-Whitney $U$-test or Kruskal-Wallis test. Univariate correlations are presented as Pearson correlation coefficients. A multiple linear regression analysis using stepwise method was performed to analyse the independent association of serum endostatin to the clinicopathological features of the cancer. Kaplan-Meier curves were used to visualise the differences of DFS, CSS and OS for patient groups stratified based on serum endostatin levels, and differences between groups were evaluated by the log rank test. The serum endostatin cutoff value $\left(172 \mathrm{ng} \mathrm{ml}^{-1}\right)$ for survival analyses was obtained from receiver operating characteristics (ROC) analysis, in which optimal cutoff scores for serum endostatin levels in discriminating CRC patients from healthy controls were defined. In all the tests, a $P$-value less than 0.05 was considered statistically significant.

\section{RESULTS}

Demographic characteristics and serum endostatin in CRC. The characteristics of CRC patients and healthy controls are presented in Table 1 and the preoperative serum endostatin levels in Table 2. Because radiation is known to induce microvascular damage and changes in microvascular density (Seemann et al, 2012) as well as to cause a pronounced fibroblastic reaction (Nagtegaal et al, 2002b), we first evaluated the effect of preoperative RT/CRT on endostatin levels of CRC patients. For this, we divided the CRC patient group into three subgroups (Table 1). The patients receiving $\mathrm{RT} / \mathrm{CRT}$ had similar endostatin levels to patients not receiving RT/CRT and matched for tumour stage and location (RT/CRT control group) (Table 2; median $154.1 \mathrm{ng} \mathrm{ml}^{-1}$ vs $\left.150.3 \mathrm{ng} \mathrm{ml}^{-1}, P=0.833\right)$. Although preoperative RT/CRT did not affect serum endostatin levels, we excluded the RT/CRT group from the subsequent analyses because of the known effects of RT/CRT on local characteristics of the tumour (Nagtegaal et al, 2002a; Seemann et al, 2012).

Serum endostatin levels were significantly increased in CRC patients without RT/CRT compared with healthy controls (Figure 1A; Table 2; median 151.1 vs 136.1, $P=0.005$ ). A ROC analysis was conducted to test the feasibility of serum endostatin in discriminating CRC patients without preoperative RT/CRT from healthy controls. It yielded an area under the curve (AUC) of 0.618 (95\% confidence interval 0.539-0.696). Using a cutoff value of $172 \mathrm{ng} \mathrm{ml}^{-1}$, discriminating specificity was 0.655 and sensitivity 0.798 .

Endostatin serum levels were similar in females and males (Table 3). The endostatin levels were significantly higher in elderly patients ( $\geqslant 65$ years) compared with younger $(<65$ years) patients $(P=0.014)$. In the controls, the effect of age on serum endostatin concentration was similar and even more distinct $(P=7.4 \mathrm{E}-10)$.

Serum endostatin levels in relation to clinicopathological parameters. The relationships between serum endostatin levels and clinicopathological variables of CRC are presented in Table 3. TNM stage I patients had significantly lower serum endostatin levels compared with more advanced stages $(P=0.014)$. Deeper local invasion $(\mathrm{T})$ was associated with a trend towards higher serum levels of endostatin $(P=0.055)$, and invasion through the muscularis propria (T1-2 vs T3-4) was associated with higher serum endostatin concentrations $(P=0.007$; Table 3; Figure $1 \mathrm{~B})$. The presence of regional $(P=0.802)$ or distant $(P=0.790)$ metastases did not have a significant effect on serum endostatin concentrations. WHO grade 3 tumours showed a tendency towards higher endostatin levels compared with grade 1 or 2 tumours

Table 1. Characteristics of the patients with CRC and the controls

\begin{tabular}{|c|c|c|c|c|c|}
\hline & $\begin{array}{c}\text { All CRC patients } \\
(n=143)\end{array}$ & $\begin{array}{l}\text { CRC patients without } \\
\text { RT/CRT }(n=113)\end{array}$ & $\begin{array}{l}\text { CRC patients with } \\
\text { RT/CRT }(n=30)\end{array}$ & $\begin{array}{l}\text { CRC patients RT/CRT } \\
\text { control group }^{\mathrm{a}}(n=31)\end{array}$ & $\begin{array}{l}\text { Healthy controls } \\
(n=84)\end{array}$ \\
\hline Age, mean (s.d.) & $67.0(11.3)$ & $68.0(11.3)$ & $63.5(10.7)$ & $68.1(10.4)$ & $66.9(10.3)$ \\
\hline \multicolumn{6}{|l|}{ Gender } \\
\hline Male & 77 (53.8\%) & 56 (49.6\%) & 21 (70\%) & 20 (64.5\%) & 44 (52.4\%) \\
\hline Female & $66(46.2 \%)$ & 57 (50.4\%) & $9(30 \%)$ & 11 (35.5\%) & $40(47.6 \%)$ \\
\hline \multicolumn{6}{|c|}{ Preoperative RT/CRT } \\
\hline Yes & $30(21 \%)$ & $0(0 \%)$ & $30(100 \%)$ & $0(0 \%)$ & \\
\hline No & $113(79 \%)$ & $113(100 \%)$ & $0(0 \%)$ & $31(100 \%)$ & \\
\hline \multicolumn{6}{|c|}{ Tumour location } \\
\hline Proximal colon & $48(33.6 \%)$ & $48(42.5 \%)$ & $0(0 \%)$ & $0(0 \%)$ & \\
\hline Distal colon & $27(18.9 \%)$ & 27 (23.9\%) & $0(0 \%)$ & $0(0 \%)$ & \\
\hline Rectum & $68(47.6 \%)$ & $38(33.6 \%)$ & 30 (100\%) & $31(100 \%)$ & \\
\hline \multicolumn{6}{|l|}{ WHO grade } \\
\hline Grade 1 & $20(14 \%)$ & $15(13.3 \%)$ & $5(16.7 \%)$ & $5(16.1 \%)$ & \\
\hline Grade 2 & 105 (73.4\%) & $84(74.3 \%)$ & $21(70 \%)$ & 24 (77.4\%) & \\
\hline Grade 3 & $18(12.6 \%)$ & $14(12.4 \%)$ & $4(13.3 \%)$ & $2(6.5 \%)$ & \\
\hline \multicolumn{6}{|l|}{ TNM stage } \\
\hline Stage I & $25(17.6 \%)$ & $18(16.1 \%)$ & $7(23.3 \%)$ & $8(25.8 \%)$ & \\
\hline Stage II & $54(38.0 \%)$ & 45 (40.2\%) & 9 (30\%) & $8(25.8 \%)$ & \\
\hline Stage III & 45 (31.7\%) & 31 (27.7\%) & $14(46.7 \%)$ & $14(45.2 \%)$ & \\
\hline Stage IV & $18(12.7 \%)$ & $18(16.1 \%)$ & $0(0 \%)$ & $1(3.2 \%)$ & \\
\hline
\end{tabular}


$(P=0.055)$. The location of the tumour did not have a significant effect on serum endostatin levels $(P=0.162)$. Tissue remodelling following necrosis could potentially release endostatin from its parent molecule, extracellular collagen XVIII. Thus, we analysed the possible association of serum endostatin level with the extent of necrosis, but no correlation was found $(P=0.769)$.

Survival analysis. To assess the prognostic significance of serum endostatin level, patients were divided into high $\left(<172 \mathrm{ng} \mathrm{ml}^{-1}\right)$ and low serum endostatin ( $\geqslant 172 \mathrm{ng} \mathrm{ml}^{-1}$ ) groups, and a KaplanMeier survival analysis was carried out. The adequacy of the cutoff point was verified with ROC analysis (data not shown). The twotiered classification of serum endostatin levels did not significantly associate with DFS (76.2\% vs $89.6 \%$; $P=0.185$; Figure 2A ), CSS (74.3\% vs $66.7 \%$; $P=0.455$; Figure $2 \mathrm{~B})$ or OS $(70.3 \%$ vs $56.4 \%$; $P=0.111$; Figure 2C).

Correlation between serum endostatin and local immune cell infiltration. Endostatin has been suggested to modulate inflammatory reactions and tumour infiltration of leukocytes (Brideau et al, 2007), and thus we evaluated the associations between serum endostatin levels and local inflammatory cell densities in CRC tissue (Table 4). Of the studied inflammatory cells, CD1a ${ }^{+}$DCs in tumour stroma, $\mathrm{CD} 83^{+}$DCs at the invasive front and mast cells in tumour stroma showed a negative correlation with serum endostatin levels.

Correlation of serum endostatin and systemic inflammation markers. We evaluated the correlations between serum endostatin levels, blood leukocyte counts and CRP concentration in patients with CRC. Of the studied parameters, CRP levels, NLR, total leukocyte count and neutrophil count showed a positive correlation with the serum endostatin levels (Table 5), and endostatin levels were higher in patients with moderate or high mGPS score as compared with those with low mGPS (Table 6).

Multivariate analyses. Next, a multiple linear regression analysis was performed to analyse the independent associations between serum endostatin levels and clinicopathological features of the cancer as well as immune cell infiltrates and systemic inflammatory cell counts. The variables analysed included age, gender, BMI, tumour location, distant metastases, nodal metastases, invasion through the muscularis propria, tumour-destructing peritumoural inflammatory infiltrate and necrosis. Of these factors, the

Table 2. Serum endostatin levels in CRC patients compared with healthy controls

\begin{tabular}{|c|c|c|c|}
\hline & $N$ & $\begin{array}{c}\text { Endostatin (serum) } \\
\mathrm{ng} \mathrm{ml}^{-1} \text {, median (IQR) }\end{array}$ & $P$-value \\
\hline Healthy controls & 84 & $136.1(109.0-166.4)$ & \\
\hline All CRC patients & 143 & $151.1(125.5-194.1)$ & vs healthy controls, $P=0.004$ \\
\hline CRC patients without RT/CRT & 113 & $151.1(125.6-195.4)$ & vs healthy controls, $P=0.005$ \\
\hline CRC patients with RT/CRT & 30 & $154.1(117.5-189.0)$ & vs healthy controls, $P=0.102$ \\
\hline RT/CRT control group & 31 & $150.3(131.0-174.4)$ & vs patients with RT/CRT, $P=0.833$ \\
\hline
\end{tabular}
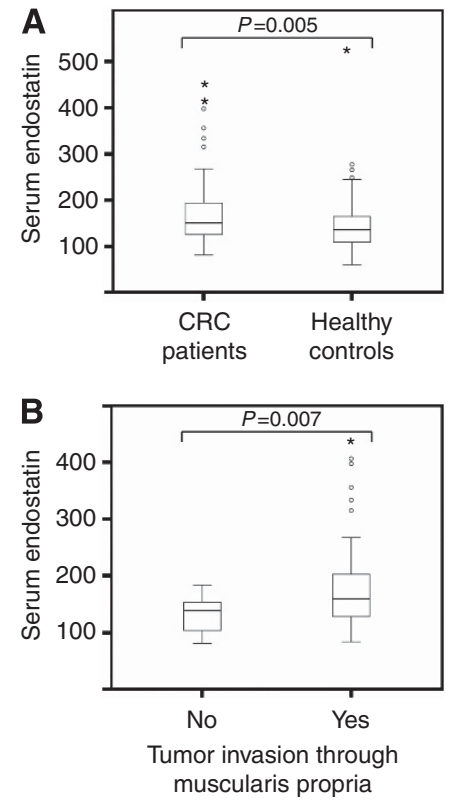
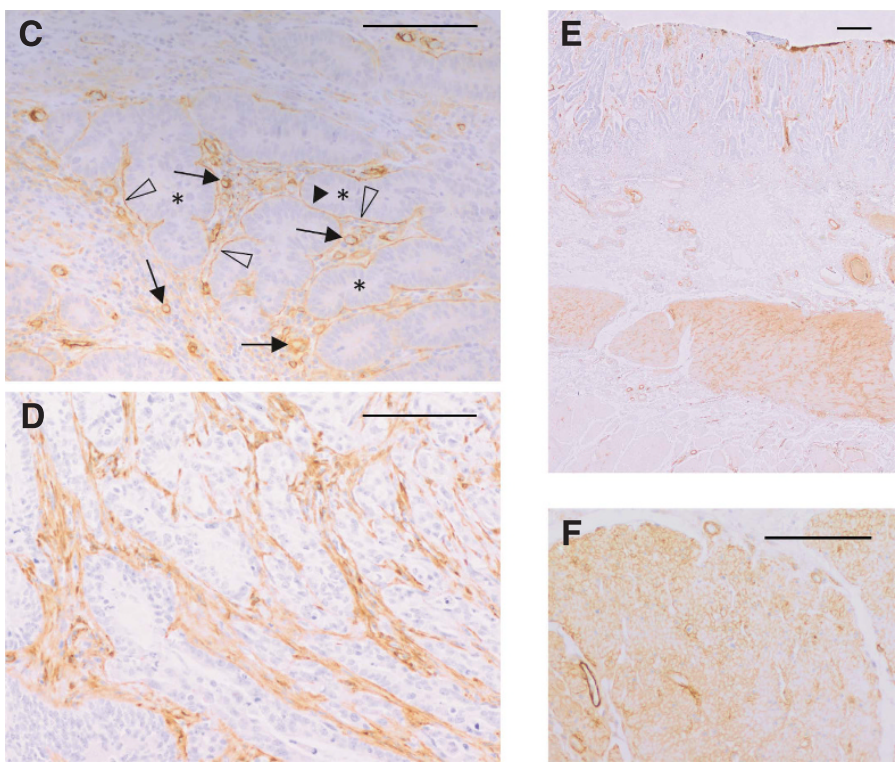

Figure 1. Serum endostatin in colorectal cancer and association with primary tumour invasion. (A) CRC patients had higher serum endostatin levels than age- and sex-matched healthy controls. (B) Tumour invasion through the muscularis propria associated with higher serum endostatin concentrations. (C-F) Collagen XVIII immunohistochemistry. (C) Blood vessels and capillary structures (arrows) show strong collagen XVIII expression, whereas no explicit staining could be found in carcinoma cells (asterisks). Collagen XVIII localised into the basement membranes surrounding the invasive tumour cell islets in some CRC cases (arrowheads). (D) In some CRC cases, collagen XVIII localised around myofibroblasts in desmoplastic tumour stroma. (E) In the bowel wall smooth muscle, collagen XVIII was detected in the muscle layer. (F) Higher magnification reveals collagen XVIII expression between muscle cells corresponding the location of basal laminae. Scale bars: c,d,f, $100 \mu \mathrm{m}, \mathrm{e}, 200 \mu \mathrm{m}$. 
Table 3. Serum endostatin levels in relation to clinical and pathological characteristics of CRCs

\begin{tabular}{|c|c|c|}
\hline & $\begin{array}{c}\text { Endostatin } \\
\mathrm{ng} \mathrm{ml}^{-1} \text {, median (IQR) }\end{array}$ & $P$-value \\
\hline \multicolumn{3}{|l|}{ Gender } \\
\hline $\begin{array}{l}\text { Male patients } \\
\text { Female patients } \\
\text { Male controls } \\
\text { Female controls }\end{array}$ & $\begin{array}{l}148.7(122.0-183.3) \\
154.2(125.6-201.9) \\
121.4(107.1-166.9) \\
146.5(113.9-166.4)\end{array}$ & 0.503 \\
\hline \multicolumn{3}{|l|}{ Age } \\
\hline $\begin{array}{l}\text { Patients }<65 \text { years }(n=40) \\
\text { Patients } \geqslant 65 \text { years }(n=73) \\
\text { Controls }<65 \text { years }(n=36) \\
\text { Controls } \geqslant 65 \text { years }(n=48)\end{array}$ & $\begin{array}{l}138.6(105.3-170.4) \\
159.7(135.7-201.3) \\
108.1(101.2-127.0) \\
154.2(137.7-179.1) \\
\end{array}$ & $7.4 \mathrm{E}-10$ \\
\hline \multicolumn{3}{|l|}{ TNM Stage } \\
\hline $\begin{array}{l}\text { Stage I }(n=18) \\
\text { Stage II }(n=45) \\
\text { Stage III }(n=31) \\
\text { Stage IV }(n=18)\end{array}$ & $\begin{array}{l}132.6(103.1-149.8) \\
164.4(135.7-222.0) \\
149.0(125.7-173.4) \\
159.7(108.9-211.3)\end{array}$ & 0.014 \\
\hline \multicolumn{3}{|l|}{ TNM classes T1-T4 } \\
\hline $\begin{array}{l}\text { T1 }(n=5) \\
\text { T2 }(n=17) \\
\text { T3 }(n=82) \\
\text { T4 }(n=9)\end{array}$ & $\begin{array}{l}147.9(109.4-156.2) \\
136.2(103.9-154.1) \\
159.5(130.2-204.6) \\
172.7(98.2-195.4)\end{array}$ & 0.055 \\
\hline
\end{tabular}

TNM classes T1-T2 vs T3-T4

\begin{tabular}{|l|l|l|}
\hline T1-T2 $(n=22)$ & $139.1(104.1-154.1)$ & 0.007 \\
T3-T4 $(n=91)$ & $159.7(127.7-203.9)$ & \\
\hline
\end{tabular}

\section{TNM classes NO-N2}

\begin{tabular}{|l|l|l|}
\hline N0 $(n=67)$ & $150.3(125.1-198.9)$ & 0.802 \\
N1 $(n=26)$ & $153.6(118.8-173.7)$ & \\
N2 $(n=19)$ & $149.0(138.1-203.9)$ & \\
\hline
\end{tabular}

\section{TNM classes M0-M1}

\begin{tabular}{|l|l|l|}
\hline M0 $(n=95)$ & $150.3(127.0-190.2)$ & 0.790 \\
M1 $(n=18)$ & $159.7(108.9-211.3)$ & \\
\hline
\end{tabular}

\section{WHO Grade 1-3}

\begin{tabular}{|l|l|}
\hline Grade $1(n=15)$ & $125.1(106.9-179.4)$ \\
Grade 2 $(n=84)$ & $152.1(128.4-188.7)$ \\
Grade 3 $(n=14)$ & $180.4(133.9-279.8)$
\end{tabular}

\begin{tabular}{|l|l|l|}
\hline WHO Grade 1-2/3 \\
\hline $\begin{array}{l}\text { Grade 1-2 }(n=99) \\
\text { Grade 3 }(n=14)\end{array}$ & $149.0(125.1-184.2)$ & 0.055 \\
\hline
\end{tabular}

\section{Tumour location}

\begin{tabular}{|l|l|l|}
\hline Proximal colon $(n=48)$ & $160.3(130.0-212.1)$ & 0.162 \\
Distal colon $(n=27)$ & $154.1(115.1-172.7)$ & \\
Rectum $(n=38)$ & $150.0(124.1-176.9)$ & \\
\hline
\end{tabular}

\section{Necrosis}

\section{None or rare $(n=67)$}

Frequent small $(n=29)$

Broad $(n=17)$

$149.0(118.4-184.2)$
$154.1(131.5-195.4)$
$153.1(109.3-212.7)$

Abbreviations: $C R C=$ colorectal cancer; $I Q R=$ interquartile range; $T N M=$ tumour, node, metastasis; $W H O=$ World Health Organization. The $P$-values are for Mann-Whitney or Kruskal-Wallis test. regression analysis using stepwise method found high age, invasion through the muscularis propria and poor differentiation as the three most important predictors of serum endostatin levels (Table 7 ), with the ability to explain $43.3 \%$ of the variability in serum endostatin levels.

In a second model, in addition to the variables above, we included the inflammatory markers, that is, the counts of stromal mast cells, peritumoural mature DCs, stromal immature DCs, serum CRP, and blood leukocytes, lymphocytes, neutrophils and NLR, which showed correlation with serum endostatin in univariate analysis. This analysis indicated that blood NLR and patient age were positively and stromal immature DC count negatively associated with serum endostatin.

Collagen XVIII immunohistochemistry. We used immunohistochemistry to assess the expression patterns of collagen XVIII, the precursor molecule of endostatin. In CRC specimens, collagen XVIII expression mainly localised to the endothelial cells of the blood vessels (Figure 1C). No explicit positivity could be found in carcinoma cells. Collagen XVIII also localised into basement membrane structures surrounding invasive tumour cell islets (Figure 1C) and around myofibroblasts in some desmoplastic tumour stroma areas (Figure 1D). We graded the quantity of positive blood vessels at tumour stroma and invasive front but found no correlation with systemic endostatin levels (data not shown). In the bowel wall, collagen XVIII was most strikingly expressed in the muscle layer between muscle cells corresponding to the location of basal laminae structures (Figure 1E and F).

\section{DISCUSSION}

Angiogenesis regulatory proteins are important modifiers of tumour growth and invasion, representing potential biomarkers for diagnostic and prognostic assessment and potential targets for CRC therapy. There is also a linkage between tumour-associated inflammatory reactions and tumour angiogenesis (Mantovani et al, 2008). Thus, it would be of importance to understand the interactions and mutual regulation of these complex systems. In this study, serum endostatin levels in CRC were first analysed in relation to major clinicopathological parameters. Second, the serum endostatin levels were correlated with blood leukocyte counts and inflammatory cell densities in CRC tissue.

We found that preoperative serum levels of endostatin are increased in CRC patients compared with healthy controls. A similar association has been reported in several human cancers and recently also in gastrointestinal cancers, including CRC, gastric cancer and hepatocellular cancer (Li et al, 2012). It has also been shown that the removal of a primary colorectal tumour leads to a decrease in serum endostatin levels (Wu et al, 2004; Peeters et al, 2005). However, our study suggests that endostatin is unlikely to prove to be a valuable tool in CRC diagnosis or follow-up, because of relatively low AUC (0.618) in discriminating the patients from healthy controls in ROC analysis. Especially, the elderly appeared to have high serum endostatin levels in the absence of CRC. The mechanism of such age-related increase in endostatin levels is unknown, but it might be associated with age-related increase in cardiovascular disease and the elevated endostatin levels in these patients (Mitsuma et al, 2007; Carlsson et al, 2013).

Li et al, 2012 have reported that increased serum endostatin levels correlate with CRC progression. Our results also showed a trend towards elevated serum endostatin levels in the presence of deeper local invasion of the tumour ( $\mathrm{T}$ classification) in univariate analysis (Table 3; $P=0.055$ ) and significant correlation between higher serum endostatin levels and the invasion of the cancer tissue through the muscularis propria (T1-2 vs T3-4) in univariate (Table 3; $P=0.007$ ) and multivariate analysis (Table 7; $P=0.032$ ). 

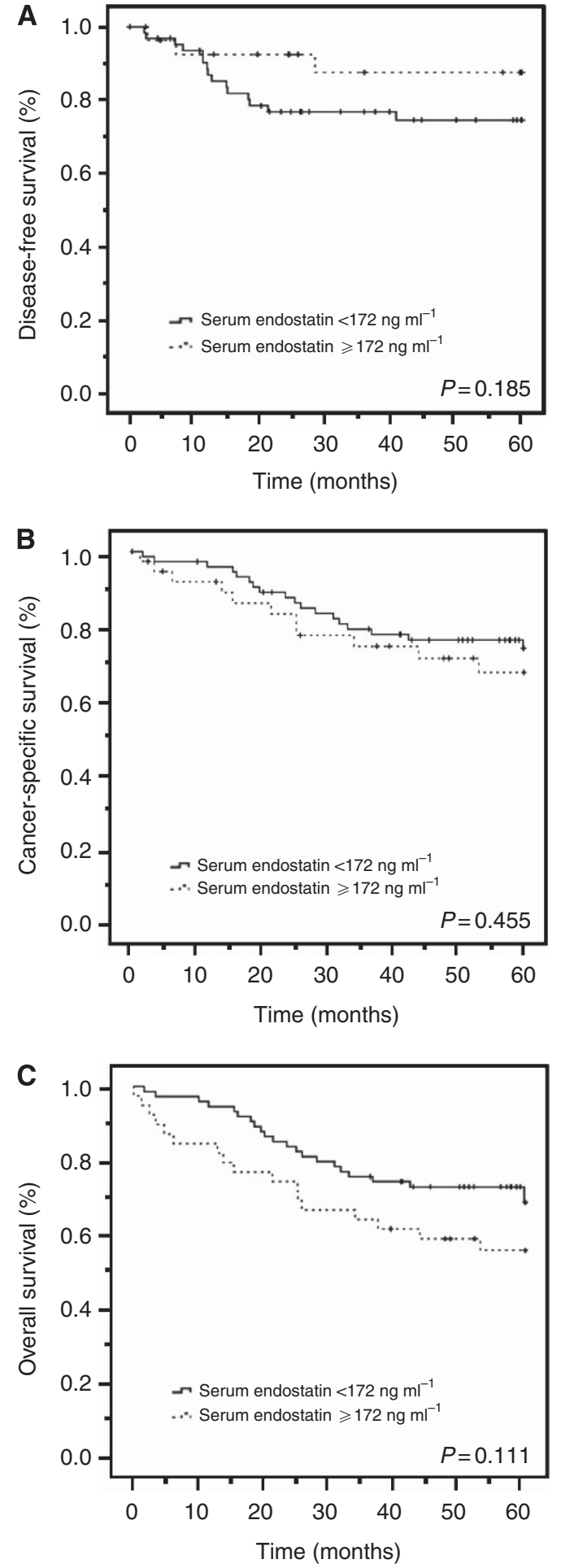

Figure 2. Kaplan-Meier survival analyses of patients with CRC. (A) Serum endostatin level had no effect on disease-free survival, (B) cancer-specific survival or (C) overall survival.

The presence of metastases did not further increase the serum endostatin levels in our study.

Immunohistochemical analysis indicated that the CRC cells do not express collagen XVIII, the source of endostatin, whereas blood vessels and capillary structures showed strong collagen XVIII positivity (Figure 1C). In some tumour areas, collagen XVIII also localised around myofibroblastic stromal cells and basement membrane structures encircling invasive tumour cell islets. In the bowel wall, collagen XVIII expression was most prominent around
Table 4. Correlation of serum endostatin levels with local areal density of inflammatory cells in CRC specimens

\begin{tabular}{|c|c|c|}
\hline & Pearson $r$ & $P$-value \\
\hline \multicolumn{3}{|l|}{ Invasive front } \\
\hline $\begin{array}{l}\text { CD3 } \\
\text { CD8 } \\
\text { FoxP3 } \\
\text { CD68 } \\
\text { CD83 } \\
\text { CD1a } \\
\text { Mast cell tryptase } \\
\text { Neutrophil elastase }\end{array}$ & $\begin{array}{r}-0.004 \\
0.074 \\
-0.023 \\
0.132 \\
-0.189 \\
-0.160 \\
-0.103 \\
0.084\end{array}$ & $\begin{array}{l}0.966 \\
0.434 \\
0.810 \\
0.164 \\
0.047 \\
0.090 \\
0.276 \\
0.378\end{array}$ \\
\hline \multicolumn{3}{|l|}{ Tumour stroma } \\
\hline $\begin{array}{l}\text { CD3 } \\
\text { CD8 } \\
\text { FoxP3 } \\
\text { CD68 } \\
\text { CD83 } \\
\text { CD1a } \\
\text { Mast cell tryptase } \\
\text { Neutrophil elastase }\end{array}$ & $\begin{array}{r}0.059 \\
0.159 \\
0.095 \\
0.023 \\
-0.140 \\
-0.281 \\
-0.214 \\
2.2 \mathrm{E}-4\end{array}$ & $\begin{array}{l}0.537 \\
0.092 \\
0.317 \\
0.805 \\
0.145 \\
0.003 \\
0.023 \\
0.998\end{array}$ \\
\hline \multicolumn{3}{|l|}{ Intraepithelial } \\
\hline $\begin{array}{l}\text { CD3 } \\
\text { CD8 }\end{array}$ & $\begin{array}{l}0.038 \\
0.042\end{array}$ & $\begin{array}{l}0.690 \\
0.671\end{array}$ \\
\hline
\end{tabular}

Table 5. Correlations between serum endostatin and CRP concentrations, and peripheral blood white blood cell counts and the NLR

\begin{tabular}{|l|c|c|}
\hline & $\begin{array}{c}\text { Endostatin } \\
\text { Pearson } r\end{array}$ & P-value \\
\hline CRP & 0.274 & 0.003 \\
\hline NLR & 0.283 & 0.003 \\
\hline Leukocytes & 0.199 & 0.035 \\
\hline Lymphocytes & 0.074 & 0.436 \\
\hline Monocytes & 0.144 & 0.130 \\
\hline Neutrophils & 0.298 & 0.001 \\
\hline Abbreviations: CRP =C-reactive protein; NLR=neutrophil/lymphocyte ratio. Numbers \\
indicate Pearson correlation coefficients (r) for logarithmically transformed variables.
\end{tabular}

Table 6. Difference in endostatin levels within mGPS

\begin{tabular}{|l|c|c|}
\hline & $\begin{array}{c}\text { Endostatin } \\
\mathbf{n g ~ m l}^{-1} \text {, median (IQR) }\end{array}$ & P-value \\
\hline mGPS & $148.2(121.3-178.1)$ & \\
\hline $0(n=88)$ & $180.4(141.7-222.0)$ & 0.017 \\
\hline $1-2(n=25)$ & $\begin{array}{l}\text { Abbreviations: IQR = interquartile range; } \mathrm{mGPS}=\text { modified Glasgow prognostic score. } \\
P \text {-value is for Mann-Whitney test. }\end{array}$ \\
\hline
\end{tabular}

smooth muscle cells of the muscle layer (Figure 1E). This suggests that the increase of serum endostatin levels may result from the degradation of collagen XVIII and the release of endostatin, when 


\begin{tabular}{|c|c|c|}
\hline Independent & Beta & $P$-value \\
\hline \multicolumn{3}{|l|}{ Model 1} \\
\hline $\begin{array}{l}\text { Age } \\
\text { Grade } \\
\text { Invasion through muscularis propria }\end{array}$ & $\begin{array}{l}0.291 \\
0.239 \\
0.192\end{array}$ & $\begin{array}{l}0.001 \\
0.008 \\
0.032\end{array}$ \\
\hline \multicolumn{3}{|l|}{ Model 2} \\
\hline $\begin{array}{l}\text { Blood NLR } \\
\text { Age } \\
\text { CD1 } a^{+} \text {cell count, stromal }\end{array}$ & $\begin{array}{r}0.231 \\
0.298 \\
-0.282\end{array}$ & $\begin{array}{l}0.013 \\
0.001 \\
0.002\end{array}$ \\
\hline
\end{tabular}

cancer cells invade through the muscle layers of the bowel wall. Although the serum endostatin levels positively correlated with $\mathrm{T}$ classification, our results indicated that there is no significant association between serum endostatin levels and survival.

Endostatin can be cleaved from collagen XVIII by several proteinases, such as MMPs-3, $-7,-9,-13,-14$ and -20 , elastase and cathepsin L (Seppinen and Pihlajaniemi, 2011). Both tumour cells and tumour-associated local inflammatory cells are able to produce several of these enzymes (Nielsen et al, 1996; Brabletz et al, 1999; Heljasvaara et al, 2005; González et al, 2007). In accordance with an earlier report ( $\mathrm{Li}$ et al, 2012), we found a significant correlation between high serum endostatin concentration and poor tumour differentiation. The expression of MMPs-7, -9, -13 and -14 have been reported to correlate with poor differentiation of CRC (Zhang et al, 2012; Yang et al, 2012, 2013; Bi et al, 2013), potentially contributing to increased serum endostatin levels in the poorly differentiated tumours. Although the correlation between the numbers of tumour infiltrating inflammatory cells and serum endostatin levels were generally weak, subpopulations of inflammatory cells may also represent a source of collagen XVIIIdegrading enzymes.

We evaluated the relationships between serum endostatin levels and local inflammatory cell infiltration in CRC tissue. Interestingly, we found a negative correlation between serum endostatin levels and the numbers of mast cells and immature DCs in tumour stroma and mature DCs at the invasive front. Our earlier study (Väyrynen et al, 2013) showed that $\mathrm{CDla}^{+}$immature DC and mast cell counts, unlike $\mathrm{T}$ cell and $\mathrm{CD} 83^{+}$mature DC counts, do not associate with stage, and these two cell types clustered far apart from other inflammatory cells in the hierarchical clustering, suggesting that these cell types are less relevant in tumourassociated immune responses. Instead, it has been reported that immature DCs and especially mast cells promote angiogenesis in certain conditions (Huang et al, 1994; Maltby et al, 2009; Fainaru et al, 2010).

The limitation of our study was the lack of experimental data. Therefore, it is not possible to conclude convincingly whether the observed negative correlations between serum endostatin levels and the numbers of tumour-infiltrating mast cells and DCs (1) reflect higher endostatin concentrations inhibiting angiogenesis, being related to a decreased number of angiogenesis-related cell types, (2) signify a direct inhibitory effect of endostatin on mast cells and DCs or (3) result from some other unconsidered factor. Moreover, a potential decrease in microvessel number or perimeter caused by endostatin could explain the decreased immune cell infiltration in the tumours (Vlems et al, 2004). However, our results suggest a specific effect on mast cell and DC infiltration, because the densities of other tumour-infiltrating leukocytes did not correlate with serum endostatin levels.
The effect of endostatin on mast cells has earlier been reported by Brideau et al, 2007 using a carcinogen-induced skin tumourigenesis model in $\mathrm{J} 4$ mice overexpressing endostatin in their keratinocytes. Elevated endostatin levels in $\mathrm{J} 4$ mice reduced the number of VEGF-C-producing mast cells in the tumour tissue, in addition to which endostatin inhibited mast cell migration and adhesion in vitro. Brideau et al, 2007 also detected reduced numbers of peritumoural lymphatic vessels in 44 mice, suggesting an inhibitory effect of endostatin on lymphangiogenesis, at least partially resulting from the effect of endostatin on VEGF-Cexpressing mast cells. Potential mechanisms of the direct interactions between mast cell and endostatin remain hypothetical. Potentially, endostatin may interact with integrins $\alpha 5 \beta 1$ and $\alpha \mathrm{v} \beta 3$, expressed by both mast cells (Columbo et al, 1995; Columbo and Bochner, 2001) and DCs (Jancic et al, 1998; Skoberne et al, 2005), which also serve as binding partners for endostatin in endothelial cells (Rehn et al, 2001).

In patients with CRC, we detected positive correlations between serum endostatin and markers of systemic inflammation, including serum CRP, blood NLR and mGPS. In recent years, it has become apparent, that systemic inflammation in patients with cancer predicts poor outcome independently of tumour stage (McMillan, 2013). The relationships between serum endostatin and systemic inflammation have not been studied in patients with cancer, and the mechanisms linking endostatin and systemic inflammation are unknown. As discussed below, the numbers of tumour-associated leukocytes did not show correlation with endostatin levels (Table 4). This suggests that other mechanisms are involved, such as products released to the circulation as cancer cells invade.

In conclusion, our results suggest that elevated endostatin levels in CRC may be released by invading cancer cells cleaving endostatin from collagen XVIII. Endostatin levels correlated with markers of systemic inflammation but the mechanisms remain speculative. There were negative correlations between serum endostatin levels and the numbers of intratumoural mast cells and DCs, which could reflect higher endostatin concentrations inhibiting angiogenesis, being related to a decreased number of angiogenesis-related cell types, or signifying a direct inhibitory effect of endostatin on mast cells and DCs.

\section{ACKNOWLEDGEMENTS}

We thank Ms. Riitta Vuento and Ms Aila White for their expert assistance, and Dr. Ritva Heljasvaara and Dr. Valerio Izzi for the critical reading of the manuscript. This work was supported by grants from Academy of Finland (24300234, 259872 and 251314), Emil Aaltonen Foundation, Finnish Cancer Foundation, Ida Montin Foundation, Oulu University Scholarship Foundation, Orion-Farmos Research Foundation, the Sigrid Juselius Foundation Northern Finland Cancer Foundation, and Vatsatautien tutkimussäätiö.

\section{REFERENCES}

Abdollahi A, Hahnfeldt P, Maercker C, Gröne H-J, Debus J, Ansorge W, Folkman J, Hlatky L, Huber PE (2004) Endostatin's antiangiogenic signaling network. Mol Cell 13: 649-663.

Bi Z, Dong L-D, Gu X-M (2013) Clinical significance of MMP-7 and PTEN expression in colorectal cancer. Hepatogastroenterology 60: 32-36.

Brabletz T, Jung A, Dag S, Hlubek F, Kirchner T (1999) beta-catenin regulates the expression of the matrix metalloproteinase-7 in human colorectal cancer. Am J Pathol 155: 1033-1038.

Brideau G, Mäkinen MJ, Elamaa H, Tu H, Nilsson G, Alitalo K, Pihlajaniemi T, Heljasvaara R (2007) Endostatin overexpression inhibits lymphangiogenesis and lymph node metastasis in mice. Cancer Res 67: 11528-11535. 
Carlsson AC, Ruge T, Sundström J, Ingelsson E, Larsson A, Lind L, Arnlöv J (2013) Association between circulating endostatin, hypertension duration, and hypertensive target-organ damage. Hypertension 62: 1146-1151.

Celik I, Sürücü O, Dietz C, Heymach JV, Force J, Höschele I, Becker CM, Folkman J, Kisker O (2005) Therapeutic efficacy of endostatin exhibits a biphasic dose-response curve. Cancer Res 65: 11044-11050.

Columbo M, Bochner BS (2001) Human skin mast cells adhere to vitronectin via the alphavbeta3 integrin receptor (CD51/CD61). J Allergy Clin Immunol 107: 554

Columbo M, Bochner BS, Marone G (1995) Human skin mast cells express functional beta 1 integrins that mediate adhesion to extracellular matrix proteins. J Immunol 154: 6058-6064.

Delaney CE, Weagant BT, Addison CL (2006) The inhibitory effects of endostatin on endothelial cells are modulated by extracellular matrix. Exp Cell Res 312: 2476-2489.

Dhanabal M, Ramchandran R, Waterman MJ, Lu H, Knebelmann B, Segal M, Sukhatme VP (1999) Endostatin induces endothelial cell apoptosis. J Biol Chem 274: 11721-11726.

Fainaru O, Almog N, Yung CW, Nakai K, Montoya-Zavala M, Abdollahi A, D'Amato R, Ingber DE (2010) Tumor growth and angiogenesis are dependent on the presence of immature dendritic cells. FASEB J 24: 1411-1418.

Faye C, Moreau C, Chautard E, Jetne R, Fukai N, Ruggiero F, Humphries MJ, Olsen BR, Ricard-Blum S (2009) Molecular interplay between endostatin, integrins, and heparan sulfate. J Biol Chem 284: 22029-22040.

Feldman AL, Pak H, Yang JC, Alexander HR, Libutti SK (2001) Serum endostatin levels are elevated in patients with soft tissue sarcoma. Cancer 91: 1525-1529.

Folkman J (2006) Antiangiogenesis in cancer therapy-endostatin and its mechanisms of action. Exp Cell Res 312: 594-607.

Folkman J, Klagsbrun M (1987) Angiogenic factors. Science 235: 442-447.

Folkman J, Long DM, Becker FF (1963) Growth and metastasis of tumor in organ culture. Cancer 16: 453-467.

González LO, Pidal I, Junquera S, Corte MD, Vázquez J, Rodríguez JC, Lamelas ML, Merino AM, García-Muñiz JL, Vizoso FJ (2007) Overexpression of matrix metalloproteinases and their inhibitors in mononuclear inflammatory cells in breast cancer correlates with metastasis-relapse. Br J Cancer 97: 957-963.

Heljasvaara R, Nyberg P, Luostarinen J, Parikka M, Heikkilä P, Rehn M, Sorsa T, Salo T, Pihlajaniemi T (2005) Generation of biologically active endostatin fragments from human collagen XVIII by distinct matrix metalloproteases. Exp Cell Res 307: 292-304.

Huang AY, Golumbek P, Ahmadzadeh M, Jaffee E, Pardoll D, Levitsky H (1994) Role of bone marrow-derived cells in presenting MHC class I-restricted tumor antigens. Science 264: 961-965.

Jain RK (2005) Normalization of tumor vasculature: an emerging concept in antiangiogenic therapy. Science 307: 58-62.

Jancic C, Chuluyan HE, Morelli A, Larregina A, Kolkowski E, Saracco M, Barboza M, Leiva WS, Fainboim L (1998) Interactions of dendritic cells with fibronectin and endothelial cells. Immunology 95: 283-290.

Kantola T, Klintrup K, Väyrynen JP, Vornanen J, Bloigu R, Karhu T, Herzig K-H, Näpänkangas J, Mäkelä J, Karttunen TJ, Tuomisto A, Mäkinen MJ (2012) Stage-dependent alterations of the serum cytokine pattern in colorectal carcinoma. Br J Cancer 107: 1729-1736.

Karumanchi SA, Jha V, Ramchandran R, Karihaloo A, Tsiokas L, Chan B, Dhanabal M, Hanai JI, Venkataraman G, Shriver Z, Keiser N, Kalluri R, Zeng H, Mukhopadhyay D, Chen RL, Lander AD, Hagihara K, Yamaguchi Y, Sasisekharan R, Cantley L, Sukhatme VP (2001) Cell surface glypicans are low-affinity endostatin receptors. Mol Cell 7: 811-822.

Kim Y-M, Hwang S, Kim Y-M, Pyun B-J, Kim T-Y, Lee S-T, Gho YS, Kwon Y-G (2002) Endostatin blocks vascular endothelial growth factor-mediated signaling via direct interaction with KDR/Flk-1. J Biol Chem 277: 27872-27879.

Kim YM, Jang JW, Lee OH, Yeon J, Choi EY, Kim KW, Lee ST, Kwon YG (2000) Endostatin inhibits endothelial and tumor cellular invasion by blocking the activation and catalytic activity of matrix metalloproteinase. Cancer Res 60: 5410-5413.

Kojima T, Azar DT, Chang J-H (2008) Neostatin-7 regulates bFGF-induced corneal lymphangiogenesis. FEBS Lett 582: 2515-2520.

Li C, Harris MB, Venema VJ, Venema RC (2005) Endostatin induces acute endothelial nitric oxide and prostacyclin release. Biochem Biophys Res Commun 329: 873-878.
Li M, Liu F, Sun P, Gao Y, Chen H, Liu H, Wang M, Chen J, Zhao Y (2012) Correlations between serum levels of vascular endothelial growth factor and endostatin with clinical pathological characteristics of patients with gastrointestinal cancers. Hepatogastroenterology 59: 1865-1868.

Maltby S, Khazaie K, McNagny KM (2009) Mast cells in tumor growth: angiogenesis, tissue remodelling and immune-modulation. Biochim Biophys Acta 1796: 19-26.

Mantovani A, Allavena P, Sica A, Balkwill F (2008) Cancer-related inflammation. Nature 454: 436-444.

McMillan DC (2013) The systemic inflammation-based Glasgow Prognostic Score: a decade of experience in patients with cancer. Cancer Treat Rev 39: 534-540.

Mitsuma W, Kodama M, Hanawa H, Ito M, Ramadan MM, Hirono S, Obata H, Okada S, Sanada F, Yanagawa T, Kashimura T, Fuse K, Tanabe N, Aizawa Y (2007) Serum endostatin in the coronary circulation of patients with coronary heart disease and its relation to coronary collateral formation. Am J Cardiol 99: 494-498.

Nagtegaal ID, Marijnen CA, Kranenbarg EK, Mulder-Stapel A, Hermans J, van de Velde CJ, van Krieken JH, Committee PR (2002a) Short-term preoperative radiotherapy interferes with the determination of pathological parameters in rectal cancer. J Pathol 197: 20-27.

Nagtegaal ID, Marijnen CAM, Kranenbarg EK, Mulder-Stapel A, Hermans J, van de Velde CJH, van Krieken JHJM (2002b) Short-term preoperative radiotherapy interferes with the determination of pathological parameters in rectal cancer. J Pathol 197: 20-27.

Nielsen BS, Timshel S, Kjeldsen L, Sehested M, Pyke C, Borregaard N, Danø K (1996) $92 \mathrm{kDa}$ type IV collagenase (MMP-9) is expressed in neutrophils and macrophages but not in malignant epithelial cells in human colon cancer. Int J Cancer 65: 57-62.

Nyberg P, Heikkilä P, Sorsa T, Luostarinen J, Heljasvaara R, Stenman U-H, Pihlajaniemi T, Salo T (2003) Endostatin inhibits human tongue carcinoma cell invasion and intravasation and blocks the activation of matrix metalloprotease-2, -9, and -13. J Biol Chem 278: 22404-22411.

O'Reilly MS, Boehm T, Shing Y, Fukai N, Vasios G, Lane WS, Flynn E, Birkhead JR, Olsen BR, Folkman J (1997) Endostatin: an endogenous inhibitor of angiogenesis and tumor growth. Cell 88: 277-285.

Peeters CFJM, de Geus L-F, Westphal JR, de Waal RMW, Ruiter DJ, Wobbes T, Oyen WJG, Ruers TJ (2005) Decrease in circulating anti-angiogenic factors (angiostatin and endostatin) after surgical removal of primary colorectal carcinoma coincides with increased metabolic activity of liver metastases. Surgery 137: 246-249.

Rehn M, Veikkola T, Kukk-Valdre E, Nakamura H, Ilmonen M, Lombardo C, Pihlajaniemi T, Alitalo K, Vuori K (2001) Interaction of endostatin with integrins implicated in angiogenesis. Proc Natl Acad Sci USA 98: 1024-1029.

Roxburgh CS, McMillan DC (2010) Role of systemic inflammatory response in predicting survival in patients with primary operable cancer. Future Oncol 6: 149-163.

Saarela J, Rehn M, Oikarinen A, Autio-Harmainen H, Pihlajaniemi T (1998) The short and long forms of type XVIII collagen show clear tissue specificities in their expression and location in basement membrane zones in humans. Am J Pathol 153: 611-626.

Schmidt A, Addicks K, Bloch W (2004) Opposite effects of endostatin on different endothelial cells. Cancer Biol Ther 3: 1162-1166discussion 1167-8.

Seemann I, Gabriels K, Visser NL, Hoving S, te Poele JA, Pol JF, Gijbels MJ, Janssen BJ, van Leeuwen FW, Daemen MJ, Heeneman S, Stewart FA (2012) Irradiation induced modest changes in murine cardiac function despite progressive structural damage to the myocardium and microvasculature. Radiother Oncol 103: 143-150.

Seppinen L, Pihlajaniemi T (2011) The multiple functions of collagen XVIII in development and disease. Matrix Biol 30: 83-92.

Siegel R, Naishadham D, Jemal A (2013) Cancer statistics, 2013. CA Cancer J Clin 63: 11-30.

Skoberne M, Beignon AS, Larsson M, Bhardwaj N (2005) Apoptotic cells at the crossroads of tolerance and immunity. Curr Top Microbiol Immunol 289: 259-292.

Suzuki M, Iizasa T, Ko E, Baba M, Saitoh Y, Shibuya K, Sekine Y, Yoshida S, Hiroshima K, Fujisawa T (2002) Serum endostatin correlates with progression and prognosis of non-small cell lung cancer. Lung Cancer 35: 29-34.

Szarvas T, László V, Vom Dorp F, Reis H, Szendröi A, Romics I, Tilki D, Rübben H, Ergün S (2012) Serum endostatin levels correlate with enhanced extracellular matrix degradation and poor patients' prognosis in bladder cancer. Int J Cancer 130: 2922-2929. 
Tjin Tham Sjin RM, Naspinski J, Birsner AE, Li C, Chan R, Lo K-M, Gillies S, Zurakowski D, Folkman J, Samulski J, Javaherian K (2006) Endostatin therapy reveals a U-shaped curve for antitumor activity. Cancer Gene Ther 13: 619-627.

Vlems F, van der Worp E, van der Laak J, van de Velde C, Nagtegaal I, van Krieken H (2004) A study into methodology and application of quantification of tumour vasculature in rectal cancer. Virchows Arch 445: 263-270.

Väyrynen JP, Tuomisto A, Klintrup K, Mäkelä J, Karttunen TJ, Mäkinen MJ (2013) Detailed analysis of inflammatory cell infiltration in colorectal cancer. Br J Cancer 109: 1839-1847.

Väyrynen JP, Vornanen JO, Sajanti S, Böhm JP, Tuomisto A, Mäkinen M] (2012) An improved image analysis method for cell counting lends credibility to the prognostic significance of $\mathrm{T}$ cells in colorectal cancer. Virchows Arch 460: 455-465.

Wilson RF, Morse MA, Pei P, Renner RJ, Schuller DE, Robertson FM, Mallery SR (2003) Endostatin inhibits migration and invasion of head and neck squamous cell carcinoma cells. Anticancer Res 23: 1289-1295.

Woo IS, Kim K-A, Jeon H-M, Hong SH, Rho SY, Koh SJ, Lee MA, Byun JH, Kang J-H, Hong YS, Lee KS, Cho C-S, Choi MG, Chung I-S (2006) Pretreatment serum endostatin as a prognostic indicator in metastatic gastric carcinoma. Int J Cancer 119: 2901-2906.

Wu FPK, Westphal JR, Hoekman K, Mels AK, Statius Muller MG, de Waal RW, Beelen RHJ, van Leeuwen PAM, Meijer S, Cuesta MA (2004)
The effects of surgery, with or without rhGM-CSF, on the angiogenic profile of patients treated for colorectal carcinoma. Cytokine 25: 68-72.

Yamaguchi N, Anand-Apte B, Lee M, Sasaki T, Fukai N, Shapiro R, Que I, Lowik C, Timpl R, Olsen BR (1999) Endostatin inhibits VEGF-induced endothelial cell migration and tumor growth independently of zinc binding. $Е M B O J$ 18: 4414-4423.

Yang B, Gao J, Rao Z, Shen Q (2012) Clinicopathological significance and prognostic value of MMP-13 expression in colorectal cancer. Scand J Clin Lab Invest 72: 501-505.

Yang B, Gao J, Rao Z, Shen Q (2013) Clinicopathological and prognostic significance of $\alpha 5 \beta 1$-integrin and MMP-14 expressions in colorectal cancer. Neoplasma 60: 254-261.

Zhang Y, Guan X-Y, Dong B, Zhao M, Wu J-H, Tian X-Y, Hao C-Y (2012) Expression of MMP-9 and WAVE3 in colorectal cancer and its relationship to clinicopathological features. J Cancer Res Clin Oncol 138: 2035-2044.

This work is published under the standard license to publish agreement. After 12 months the work will become freely available and the license terms will switch to a Creative Commons AttributionNonCommercial-Share Alike 3.0 Unported License. 